\title{
Trachyte weathering in the urban built environment related to air quality
}

\author{
Luigi Germinario ${ }^{1 *} \mathbb{0}$, Siegfried Siegesmund ${ }^{2}$, Lara Maritan ${ }^{1}$, Klaus Simon $^{2}$ and Claudio Mazzoli
}

\begin{abstract}
Decay of trachyte used as building stone in urban environment was investigated through the analysis of crusts and patinas found on trachyte of the Euganean Hills in the Renaissance city walls of Padua, northeastern Italy. Mineralogical and microstructural characteristics of the alteration products, as well as major- and trace-element chemical composition, were determined by optical microscopy, SEM-EDS and X-ray mapping, XRPD, and LA-ICPMS. The results are discussed referring to environmental parameters, in particular concerning air quality and anthropic pollution sources. The influence of composition of the stone and other neighboring materials on specific weathering processes is also debated. The formation of crusts and patinas turns out to be mainly due to exogenous processes. Enrichment in heavy metals and carbonaceous matter derives from the deposition of particulate emitted during fuel combustion by road vehicles, domestic heating and, secondarily, industrial activities. The particulate is typically cemented by calcite, mainly mobilized after dissolution from nearby mortar joints, or iron, released by leaching from iron-bearing minerals, reprecipitated according to $\mathrm{pH}$ fluctuations. Gypsum layers were rarely observed. Generally, composition of the weathering crusts and patinas of Euganean trachyte proves to be an informative marker for the relevant environmental conditions and their evolution.
\end{abstract}

Keywords: Building stone decay, Air pollution, Weathering crust, Mortar dissolution, Leaching, Mineral mobilization, Euganean trachyte

\section{Introduction}

Air quality is a key factor affecting stone weathering in urban environment, where concentration of stoneworks is generally large and, at the same time, human activities are intense and diverse. The latter change in time and space, and so does their contribution to pollution. Time variations in quantity and quality of pollutant emissions strongly depend on changes in fuel use [1]. $\mathrm{SO}_{2}$ emissions have represented a major concern until the 20th century, but considerably declined in Europe during the last decades, by one or two orders of magnitude in cities, determining a general improvement of air quality [2]; however, globally, increasing coal demand according to recent projections [3-5] and, for example, the latest changes in climate policies in the USA [6], may revert this tendency.

\footnotetext{
*Correspondence: luigi.germinario@gmail.com

1 Department of Geosciences, University of Padova, Via Gradenigo 6,

35131 Padua, Italy

Full list of author information is available at the end of the article
}

Nowadays, the higher concentration of other pollutants, such as $\mathrm{N}$ oxides $\left(\mathrm{NO}_{\mathrm{x}}\right)$, particulate matter $(\mathrm{PM})$, and $\mathrm{O}_{3}$, must be reassessed. Road transport, domestic heating, industry, and power plants are the main pollution sources in urban areas, but their relative importance has changed with time as well [7].

In the modern urban environment, a multi-pollutant scenario arises with a major incidence of airborne particulate, having high concentration of elemental C (soot) and volatile organic compounds (VOC), with fuel combustion from road traffic as the main contributor $[8,9]$. This carbonaceous matter exhibits high specific surface area and contains heavy metals and aluminum-silicon particles, which act as catalysts and adsorbents for organic compounds [10]. Pollutant interaction with stone preferentially occurs through short-range dry deposition. Overall, the well-known processes of crust formation are becoming less significant in favor of soiling, characterized by an increasing enrichment in organic C, i.e., aliphatic and polycyclic aromatic hydrocarbons [11-14]. In 
urban environment, dry deposition is more significant than wet deposition, but a notable danger is still represented by short drizzles, fog, and dew, which have higher $\mathrm{pH}$, do not remove previous acid deposits, and provide sufficient moisture for their chemical activation [15-17].

Most studies on the interaction between building stone and urban environment have focused so far on weathering of carbonate rocks, their dissolution, and formation of gypsum crusts [18]; other rock types have been investigated more rarely.

Deterioration of trachyte has also received scarce attention in the literature, not only because of its generally good durability. In fact, its use is historically less common if compared to other volcanic rocks, i.e., tuff above all, andesite, and basalt. These rock types have been quarried in Europe, Latin America, Middle and Far East and so on, and employed by some of the most important ancient civilizations, like the Romans, Egyptians, Greeks, Incas, and Aztecs $[19,20]$. Trachyte use has not been such widespread, with an exploitation mostly limited to Europe, namely Italy, Germany, Czech Republic, and France, as well as the Azores and Canary Islands.

Most studies on trachyte weathering have focused on coastal salt-aggressive environments, such as those of Venice and Naples in Italy, and the Azores islands. Several deterioration patterns have been observed, including scaling, powdering, exfoliation, blistering, differential erosion, and efflorescence. They result to be mainly determined by cyclic processes of in-pore salt crystallization related to sea-salt supply. The phases involved are halite, gypsum, thenardite, and mirabilite and, in indoor environments, also trona and natron [2124]. Only Lazzarini et al. [23] have addressed in detail the on-site decay of trachyte of the Euganean Hills, subject of the present paper; in this regard, Germinario et al. [25], in a recent work, explored the link between the changing petrophysical and mechanical properties of that stone and its diverse durability and resistance to water-driven weathering.

Few studies have also focused on trachyte used in inland continental climates, as in Czech Republic [26] and Germany [27]. In particular, Graue et al. [27] have examined weathering crusts of trachyte in industrial, urban and rural environments, showing how their thickness, grain size, and enrichment in heavy metals and other exogenous components well correlate with different degrees and sources of anthropogenic air pollution.

In this paper, the problem of trachyte decay in urban environment is tackled investigating the mineralogical, microstructural and chemical characteristics of weathering crusts and patinas detected on trachyte of the Euganean Hills used in the Renaissance city walls of Padua, in northern Italy. Trachyte alteration is discussed referring to environmental parameters, in particular concerning air quality and anthropic pollution sources, which are examined based on measured or modeled pollution data and placed in a cause-effect relationship with the weathering products. The influence of composition of the stone and other neighboring materials on specific weathering processes is also debated.

\section{The city walls of Padua}

Padua has a composite wall system surrounding the historical district gone through millennia of history and several layouts and building phases, dated to the Roman age, the Middle Ages (12th-14th century), and, finally, the Renaissance.

The latest wall circuit, the best preserved today, was built roughly following the previous Medieval perimeter by the Republic of Venice Serenissima, an ancient state of northern Italy (697-1797). The supremacy of Serenissima in Padua began in 1405, but the works for new defensive walls started one century later, during and after the war with the League of Cambrai, an alliance formed in 1508 by the major European powers attempting to hinder the expansionist goals of Venice. The difficulties encountered in defending Padua, the most important mainland city, and the ongoing technological military innovations forced Serenissima to plan the construction of a new fortification system. This started in 1513 and continued until half of the century, with the realization of walls with an $11 \mathrm{~km}$ perimeter, 19 bastions, 8 gates, and several bridges, protected by moats, rivers, and channels (Fig. 1). What can be seen today is the result of the extensive modifications and demolitions of several parts of the curtain walls and two gates occurred under urbanization pressure from the 19th century $[28,29]$.

The Renaissance wall system was built almost completely using bricks for the outer surfaces, with a core filled with rubble of bricks and stones consolidated with mortar. Trachyte was used not only as stone blocks in the core. It was employed for stringcourses, parapets, ashlars on angular ends of the bastions and other minor elements, as well as for building some of the gates (Porta Savonarola, Porta San Giovanni, Porta Santa Croce, and Porta Liviana-Pontecorvo).

A set of 22 trachyte samples was collected on four different segments of the Renaissance walls for analyzing their weathering crusts and patinas. Stringcourses on curtains and roundels as well as ashlars of an angled bastion were sampled, their localization being indicated in Fig. 2. During sampling, spots with different exposure were chosen; in the case of stringcourses, samples from the upper, frontal and lower surface were collected. To our knowledge, no cleaning restoration intervention was ever carried out on the sampled stone elements. 

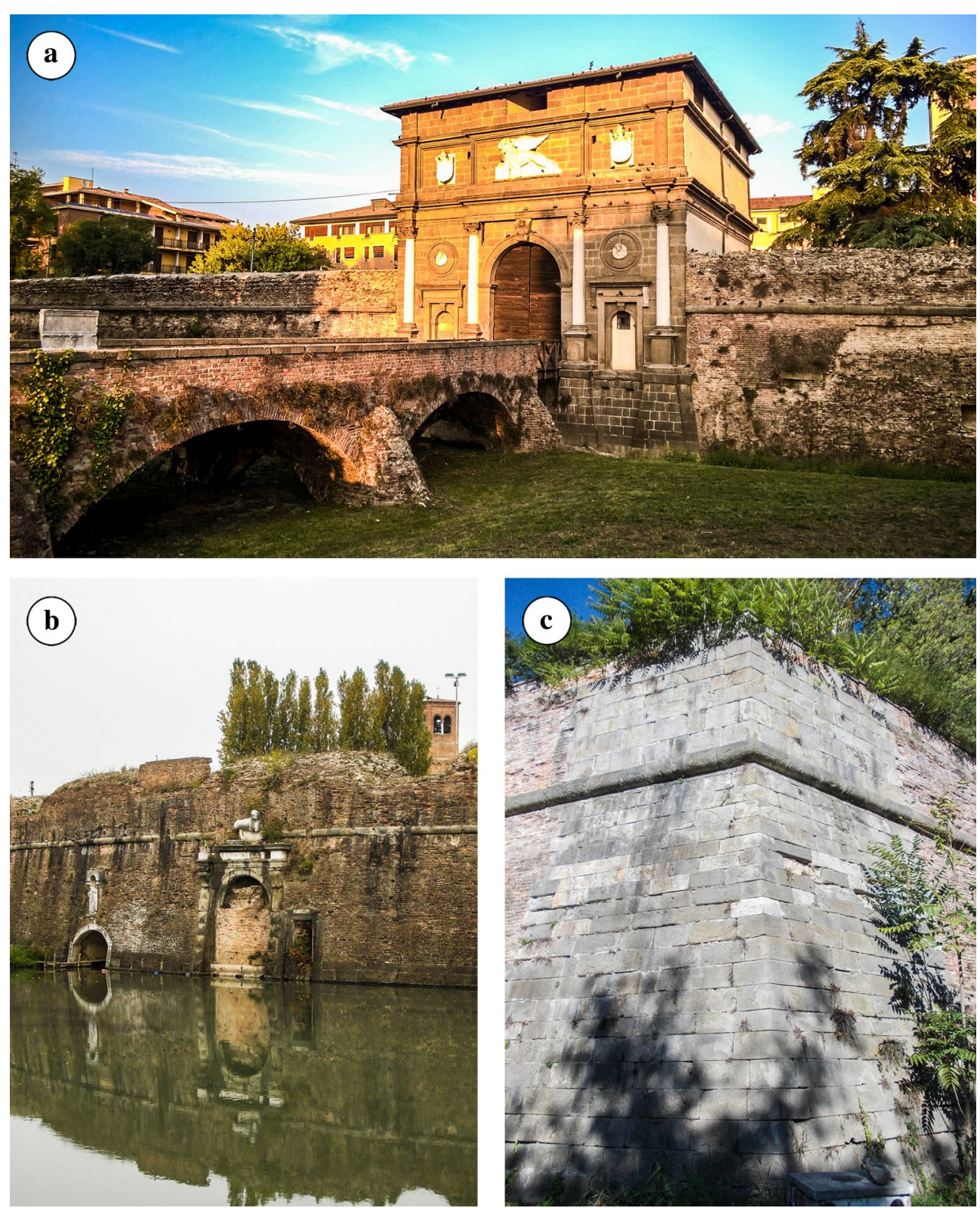

Fig. 1 The Renaissance city walls of Padua raised by the Republic of Venice Serenissima: a Porta Savonarola gate, with a wall segment; b Castelnuovo circular bastion with a water gate facing a channel; c Cornaro pentagonal bastion

\section{Euganean trachyte}

The trachyte used in the Renaissance walls was extracted in the quarry district of the Euganean Hills, a group of hills located near Padua formed by a sedimentary succession of limestones and marls of the upper Jurassic-lower Oligocene, a Paleogene volcanic and hypabyssal series, and Quaternary detrital deposits. Trachytes are ascribable to a subvolcanic series dated to the lower Oligocene, and have acid to intermediate composition and moderate Na-alkaline affinity [30, 31].
From a petrographic point of view, Euganean trachyte is a holocrystalline to hypocrystalline rock with porphyritic texture and a mineralogical composition given mostly by feldspars (anorthoclase, plagioclase, and sanidine, in diverse combination), biotite and, occasionally, augite and kaersutite. The accessory minerals typically comprise quartz, cristobalite, Ti-magnetite, ilmenite, apatite, and zircon. Groundmass is composed by alkalifeldspar microlites usually with a felty texture, or sometimes showing preferred orientations [32]. 

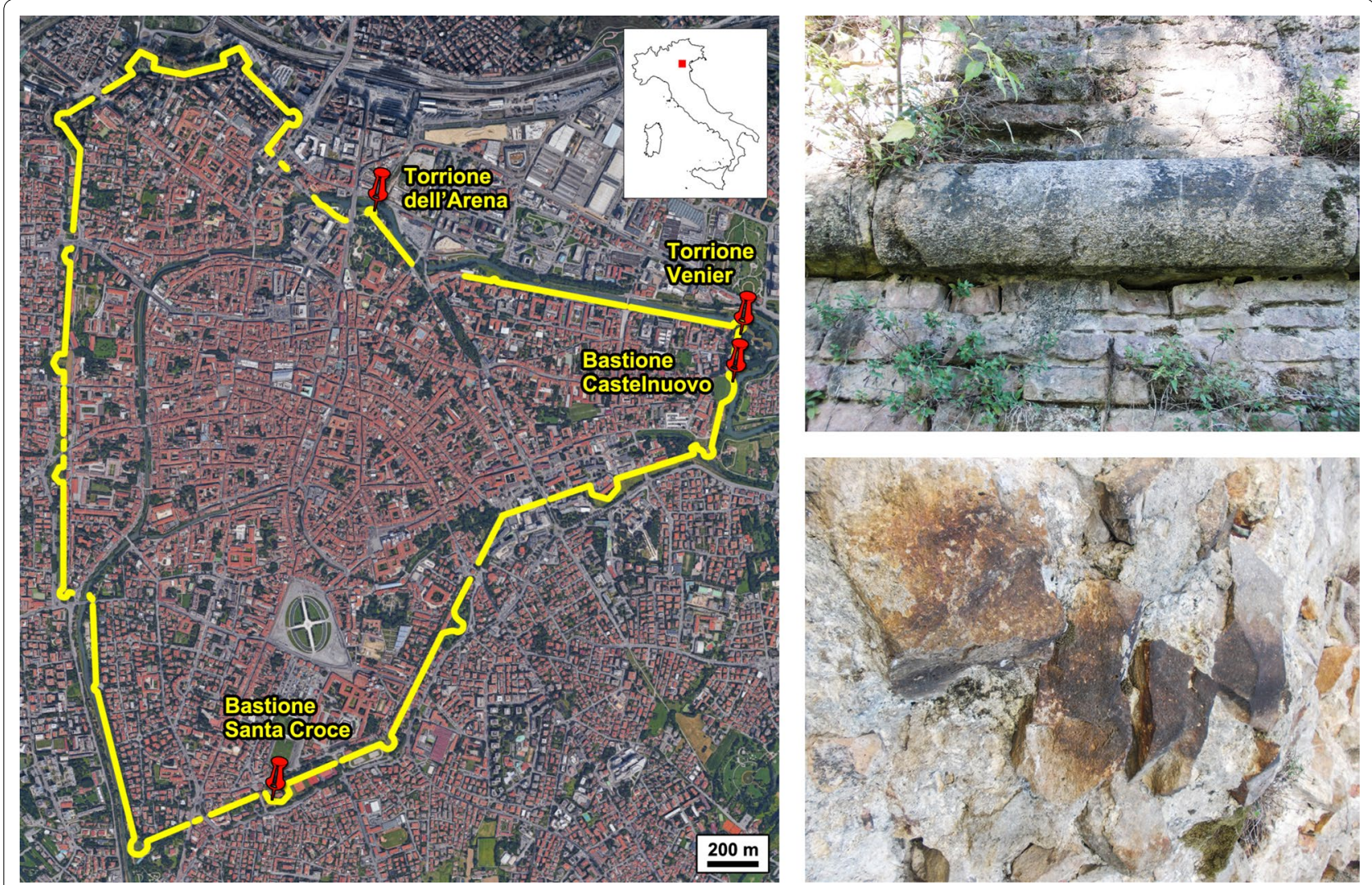

Fig. 2 The present-day circuit of the Renaissance city walls of Padua (satellite image from $\odot 2016$ Google), with sampling areas indicated, and two examples of weathering crusts and patinas on Euganean trachyte used for a stringcourse and as filling material in the wall core

The exploitation of Euganean trachyte started in PreProtohistory, but became more intense from Roman times. This material has been extensively used as carving and building stone in northern and central Italy and nearby its borders. Querns, mortars, cippi, milestones, steles, urns, tombstones, and sarcophagi comprise the most common artifacts crafted with trachyte all through the centuries. Euganean trachyte was widely used in the built environment too, as an instance for the admirable roads and other great infrastructure of the Roman age or the monumental architecture and construction from the Middle Ages and Renaissance. Indeed, with the rise of the Republic of Venice Serenissima, stone construction was given a substantial boost, and trachyte was largely employed in public buildings, churches, monasteries, monumental gates, defensive walls and private residences, as well as for paving squares and streets; the most striking examples can be admired in Padua and Venice $([32,33]$ and references therein).

\section{Experimental methods}

The trachyte samples collected on the walls of Padua were analyzed in order to determine their mineralogical, microstructural and chemical characteristics, using the facilities of the Geoscience Center of Georg-August-Universität Göttingen.

Rock thin sections both parallel and perpendicular to the exposed surface were investigated with a polarizedlight microscope and a field-emission scanning electron microscope (FE-SEM) FEI Quanta 200 FEG equipped with a $\mathrm{ZrO} / \mathrm{W}$ Schottky field-emission gun and detector for energy-dispersive X-ray spectroscopy (EDS). In addition to usual observations and phase identifications, carried out on gold-coated samples, the SEM was used for acquiring X-ray elemental maps of selected cross sections, operating at $20 \mathrm{kV}$ acceleration voltage, and scanning a grid of $512 \times 400$ pixels with a dwell time of $300 \mathrm{~ms}$.

Powdery and incoherent samples were analyzed by X-ray powder diffraction (XRPD) with a Philips PW 1800 
diffractometer equipped with $\mathrm{Cu}$ anode operating at $45 \mathrm{kV}$ and $30 \mathrm{~mA}$, measuring with scan steps of $0.02^{\circ} 2 \theta$ in the range $3-70^{\circ} 2 \theta$ and an integration time of $4 \mathrm{~s}$.

Furthermore, analyses by laser ablation inductively coupled plasma mass spectrometry (LA-ICPMS) were performed in order to determine major- and trace-element composition of both the altered layers and fresh host rock. The latter, prepared as polished samples embedded in epoxy, was analyzed with a Thermo Scientific Element 2 double-focusing magnetic-sector spectrometer coupled to a Resonetics Resolution $193 \mathrm{~nm}$ Ar-F excimer laser; data were acquired along $1.5 \mathrm{~mm}$-long profiles and average compositions calculated. Instead, the crusts and patinas were analyzed as they are, given the difficulty in preparing polished sections due to their limited thickness. For these samples, a Perkin Elmer ELAN DRC II quadrupole spectrometer was used coupled to a Lambda Physik COMPex 110193 nm Ar-F excimer laser. Data were acquired on profiles on the entire sample surface (centimetric in size) and average compositions calculated. Both lasers operated at $7 \mathrm{~Hz}$ repetition rate, $3 \mathrm{~J} / \mathrm{cm}^{2}$ fluence, $7 \mu \mathrm{m} / \mathrm{s}$ velocity, and using a spot size of
$120 \mu \mathrm{m}$. Element concentrations were calculated with Iolite v2.5 software package, by a script based on the following procedure: the LA-ICPMS signal is first smoothed by ratioing to an appropriate denominator isotope present in the sample and standard $\left({ }^{29} \mathrm{Si}\right)$; the element ratios are standardized with NIST 610 glass reference material; then, they are normalized to oxides sum to reach $100 \%$, including all the elements [34].

\section{Weathering analysis \\ Mineralogy and microstructure}

Microscopic observations reveal that the thickness of the weathering crusts and patinas on the exposed surfaces is rather limited, often below few tens of micrometers, and only exceptionally may reach few hundreds of micrometers. Sometimes, powdery and incoherent deposits are also observed.

Almost all the samples have a high $C$ content, responsible for the black-greyish color of many crusts and patinas. Subspherical carbonaceous particles may be isolated, grouped in small clusters (Fig. 3a), or form extensive layers, possibly displaying fractures and microcracks
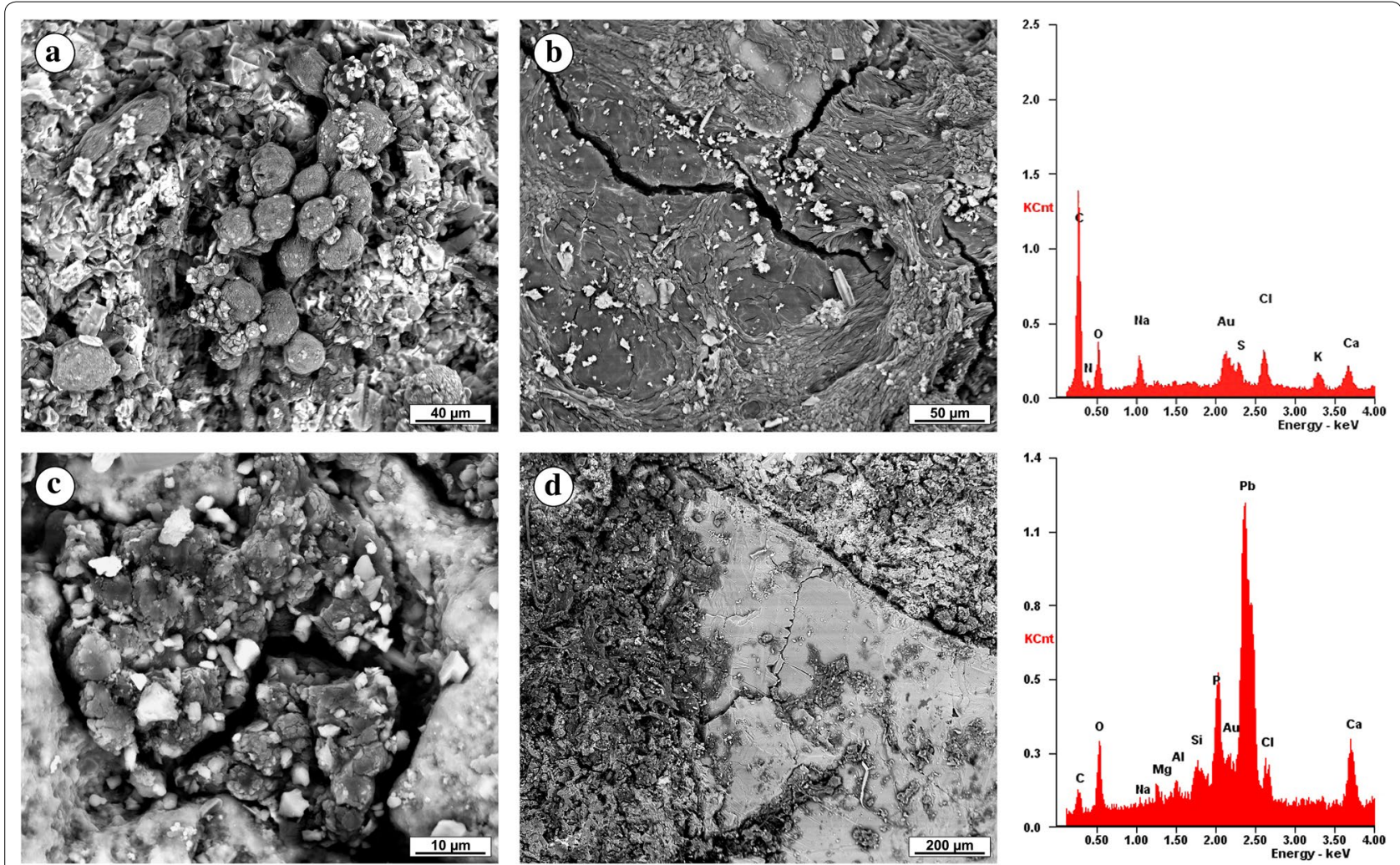

Fig. 3 SEM-BSE photomicrographs showing different features of the carbonaceous fraction (darker in the images) detected on the weathering crusts and patinas of Euganean trachyte and its microchemical composition by EDS measured on two different spots (signal from gold coating is also visible). a Cluster of subspherical carbonaceous particles. b Microcracked patina with crumbled fine-grained feldspars. c Carbonaceous mass with Fe oxides, carbonates, and quartz. d Aggregates of carbonaceous particles arranged along the edges and the internal fractures of a plagioclase phenocryst 
(Fig. 3b). Soot represents a container for further accumulation of pollutants, indeed it may be rich in heavy metals, especially $\mathrm{Pb}$, or include exogenous quartz, aluminosilicate minerals, chlorides, $\mathrm{Al}$ oxides, etc.

The airborne carbonaceous pollutants are frequently trapped in crusts formed by microcrystalline calcite and, secondarily, dolomite (Fig. 4). The high concentration of these phases cannot be traced back to trachyte composition, since they are originally present in low or negligible amount. A high content of quartz is often detected as well.

The carbonaceous particles may be also associated with a matrix rich in Fe, present as oxides and hydroxides or in amorphous state, giving a general brown-reddish color, in possible combination with carbonates (Fig. 3c).

In the thinnest patinas, there are virtually no intermediate alteration layers between the host rock and the carbonaceous components, the adhesion of which takes place directly on the feldspars constituting the substrate; their fine grain size and crumbled appearance, which creates a porous surface favoring $\mathrm{C}$ deposition, suggests former processes of granular disintegration. $\mathrm{C}$ accumulates mainly on the groundmass or fine-grained phenocrysts, taking advantage of intercrystalline spaces and higher porosity, whereas large phenocrysts are less affected (Fig. 3d).

Gypsum crusts are detected on a single sample, very close to a mortar splash by the joint of two trachyte blocks. Its collocation, on the lower side of a stringcourse, was a shelter against direct rainfall and washing out. The microscopic investigation revealed a complex stratigraphy (Fig. 5). The superficial layer is composed of a network of acicular or tabular gypsum crystals with rosette-like intergrowths, which embeds carbonaceous particles, but in rather low concentration. The second underlying layer is composed of amorphous silica. The third layer is constituted mostly of calcite, directly crystallized on the host rock. The presence of separate gypsum and calcite levels suggests a slow-rate alteration process, started with the crystallization and growth of a carbonate layer and its later, partial reaction with $S$, mostly limited to its outermost part. The gypsum layer represents a rather compact domain, whereas the underlying host rock shows a high degree of fracturing.

The XRPD analyses of powdery and incoherent deposits sampled on trachyte confirm the occurrence of some of the mineral phases detected through the SEM observations and microanalyses. Quartz, calcite, and dolomite are the major components, while the other identified phases comprise minerals from the host rock, like feldspars and biotite, or from their alteration, such as illite and chlorite (Fig. 6).

\section{Major- and trace-element composition}

The LA-ICPMS analyses of major elements (Table 1) substantially confirm the occurrence of two main alteration types, characterized by a high concentration of calcite and Fe. If the average composition of Euganean trachyte in Germinario et al. [32] is taken as reference, the calcite crusts and patinas show an increase of $\mathrm{CaO}$ by a factor from 7 up to 60, corresponding to a maximum concentration of $86 \%$. At the same time, a decrease in the content of $\mathrm{SiO}_{2}, \mathrm{Al}_{2} \mathrm{O}_{3}, \mathrm{Na}_{2} \mathrm{O}$, and $\mathrm{K}_{2} \mathrm{O}$ is always evident, up to a maximum of $87,93,97$, and $98 \%$, respectively. A modest increase of $\mathrm{MgO}$, associated with dolomite presence, is also noticeable. The different ratios between $\mathrm{CaO}$
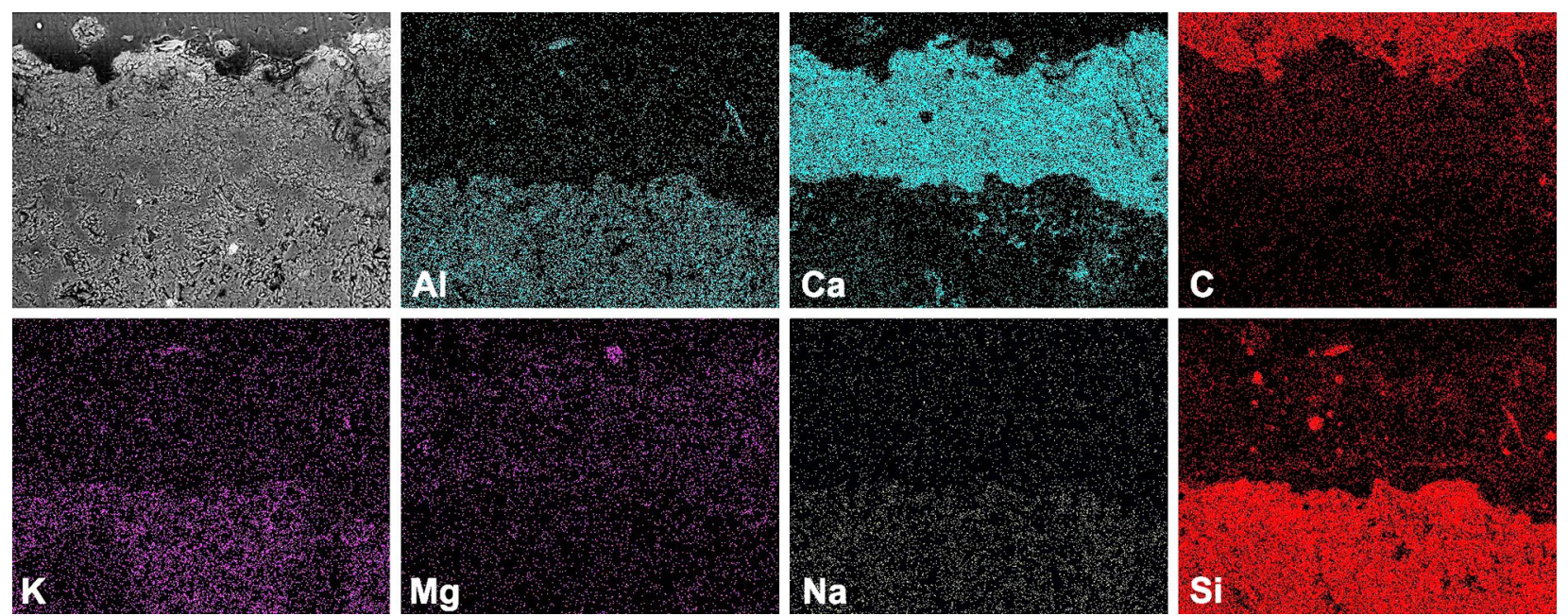

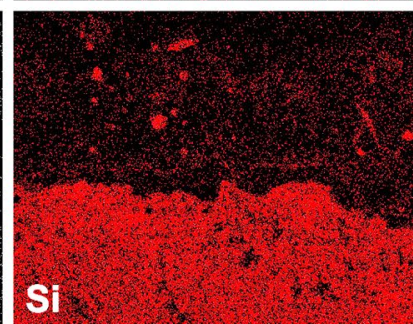

Si

Fig. 4 SEM-EDS X-ray maps of a calcite crust of Euganean trachyte prepared as epoxy-embedded cross section, with the exposed surface displayed on the top (field size: $523.6 \times 406.6 \mu \mathrm{m}$ ) 


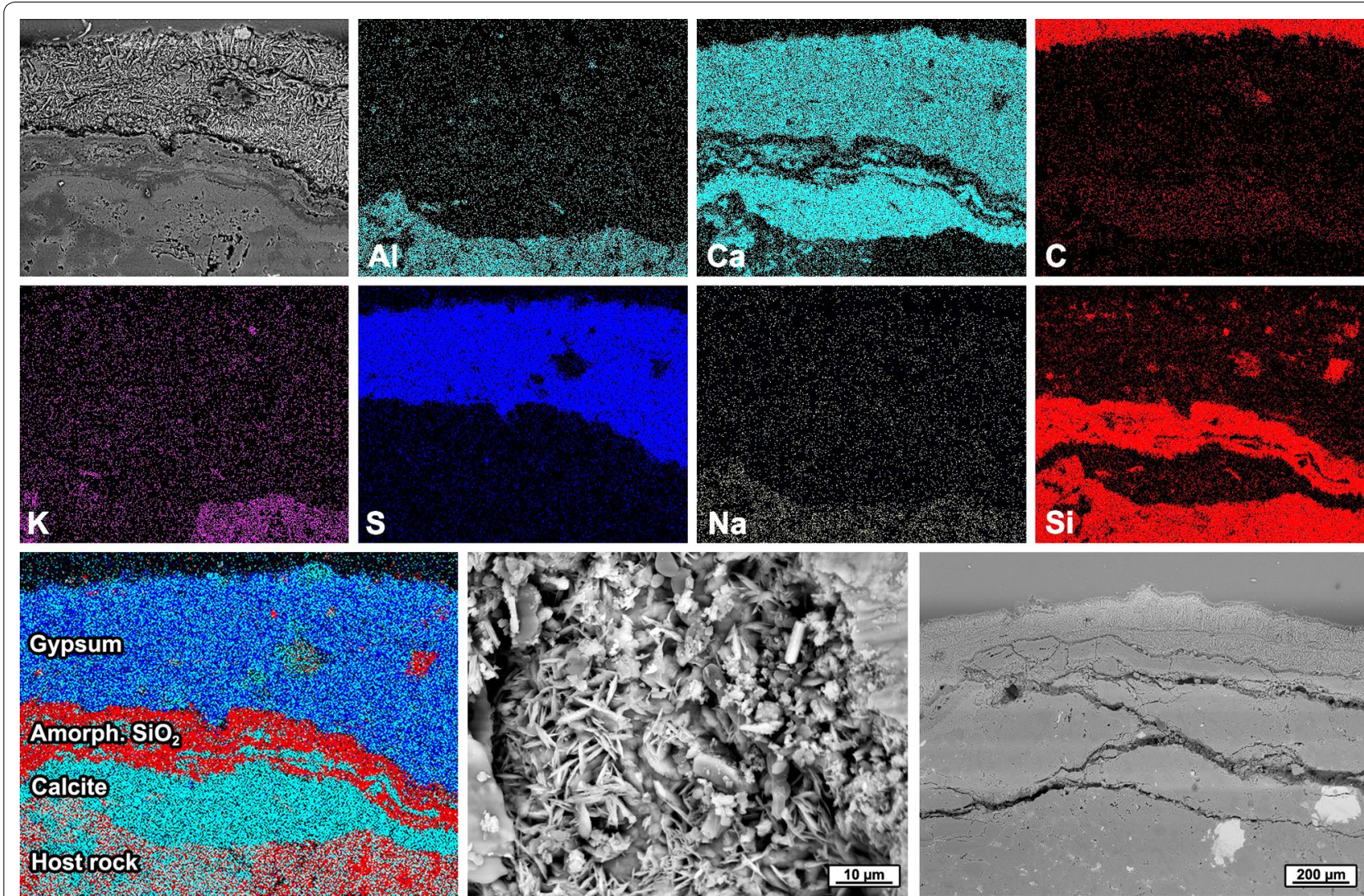

Fig. 5 SEM-EDS X-ray maps of a gypsum crust of Euganean trachyte prepared as epoxy-embedded cross section, with the exposed surface displayed on the top (field size: $524.5 \times 407.3 \mu \mathrm{m}$ ). Details of the gypsum crystals and the fractured host rock beneath the crust are showed in the SEM-BSE photomicrographs

and the feldspar-related elements reveal different degrees of alteration and homogeneity of the weathering layers, hence to what extent the silicate host rock has been obliterated by newly formed phases. As pointed out before, enrichment in carbonates and Fe may be associated but, when the latter is predominant, a Fe increase by a factor up to 6.5 is recorded. Although a general surface sulfation is often evident, only in the gypsum crust a large increase in $\mathrm{SO}_{3}$ is reported, by a factor of 2487 , corresponding to a concentration of $25 \%$, which almost completely hides the silicate composition of the host rock, in association with the high content of $\mathrm{CaO}$.

Further indications are given by the concentration of trace elements (a selection is reported in Table 2, while the complete dataset is included in Additional file 1). In comparison to the host rock, a remarkable enrichment in heavy metals of the crusts/patinas is evident (Fig. 7), especially in $\mathrm{V}, \mathrm{Cr}, \mathrm{Ni}, \mathrm{Cu}, \mathrm{Zn}, \mathrm{As}, \mathrm{Cd}, \mathrm{Sn}, \mathrm{Sb}, \mathrm{Pb}$, and $\mathrm{Bi}$. As an instance, $\mathrm{Pb}$ results to be increased by a factor of over 1700. The highest absolute concentrations are reported for $\mathrm{Cu}, \mathrm{Zn}$, and $\mathrm{Pb}$, equal to $1009,11,460$, and
$25,800 \mathrm{ppm}$, respectively. No significant mobilization of heavy metals into the host rock is detected [35].

As also summarized in Fig. 8, when the host rock is shielded by thick, homogeneous and well-developed crusts, as those rich in calcite or gypsum, the near-surface concentration of heavy metals is lower on average, i.e., the absorption of pollutants is more limited. Calcite and gypsum tend to form microcrystalline domains more compact than the underlying host rock, so that mechanisms of dry and wet deposition of pollutants are hindered. This is confirmed by a higher content of heavy metals on the stone surfaces exhibiting only a weak incipient alteration, maybe only recently exposed (e.g., due to previous detachment of outer layers). On the other hand, non-uniform crusts, which do not entirely cover the host rock, represent an intermediate condition: storage of airborne carbonaceous particles and surface accumulation of metallic pollutants are enhanced because of a relatively high porosity, given by a mix of disaggregated host rock and uneven, incomplete and scarcely adhering crystallization of newly formed phases. In this case, an 


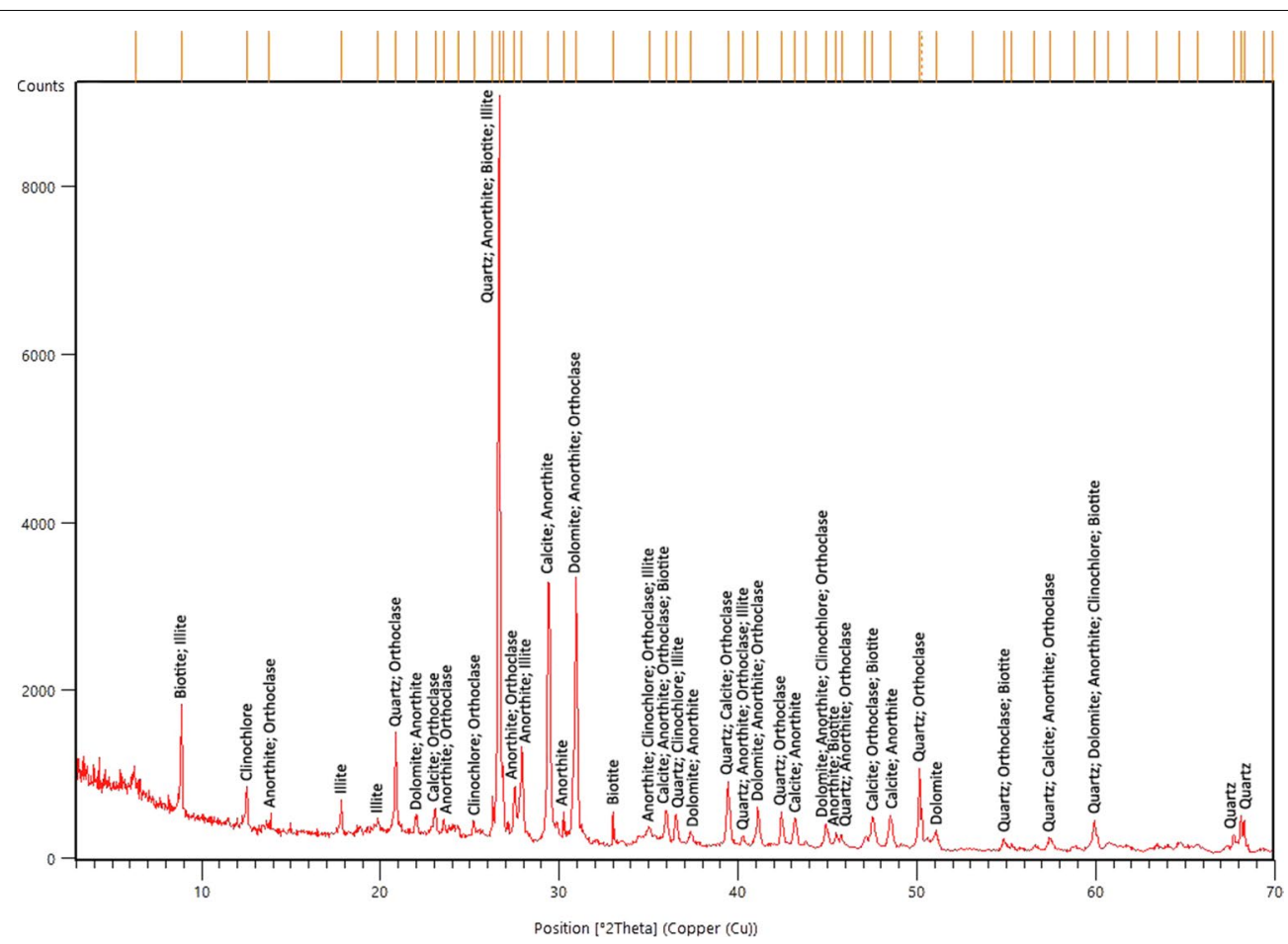

Fig. 6 XRPD spectrum of a powdery deposit on Euganean trachyte, showing a composition given mostly by quartz, calcite, and dolomite

enrichment in $\mathrm{CaO}, \mathrm{Fe}_{2} \mathrm{O}_{3}$, and heavy metals is clear, but the contribution of the silicate substrate to the chemical composition of the stone surface is still distinct.

Finally, the relationship between trachyte sampling point and sample composition suggests the following considerations: the samples collected on the frontal sides of stringcourses or ashlars feature a higher concentration of carbonates on average, thus indicating a major incidence of calcite-rich alteration on vertical surfaces; the samples collected on the lower sides, including the gypsum crusts, display lower concentrations of heavy metals; no specific alteration trends dependent on the sampling site were recognized.

\section{Correlation with air quality Environmental setting}

In order to establish a correlation between trachyte alteration and air quality, it is necessary to describe the environmental setting the stone interacts with.

Padua is a city of about 200,000 people in the Veneto region, northeastern Italy, located in the Po Plain about $20 \mathrm{~km}$ far from the Venetian Lagoon and $40 \mathrm{~km}$ from the coastline of the Adriatic Sea.

The climate is humid temperate (Köppen classification: "Cfa"). It features hot summers, with record maximum temperatures usually exceeding $35^{\circ} \mathrm{C}$, and mild to cold winters, when minimum temperatures may easily drop below $0{ }^{\circ} \mathrm{C}$. The most humid period in the year is between fall and winter, whereas late-spring and summer months are the driest. Rainfall is concentrated during fall and spring, while winter has the lowest precipitation. Spring is usually the windiest season (Table 3 ).

The $\mathrm{pH}$ value of rainfall is from 5.5 to 6 on average, ${ }^{1}$ which is the conventional value of unpolluted rainwater, i.e., 5.6 [36].

Concerning air quality, the most significant pollution sources in Padua, besides road traffic and domestic combustion, are the only two major industrial plants in the city area, namely a waste-to-energy incinerator and a steel plant, about 3 and $6 \mathrm{~km}$ far from downtown, respectively. Compared to the pollution measured in background areas, traffic zones present a concentration of $\mathrm{NO}_{\mathrm{x}}$ increased by a factor of 1.5 , whereas near industrial plants the same increase in the concentration of $\mathrm{SO}_{2}$ is registered, as well as an enrichment in heavy metals in the PM fraction, by a factor up to over 2 (Table 4). Finally,

\footnotetext{
${ }^{1}$ No recent institutional data are available, so the value indicated has been assumed from alternative sources: dated measurements in Padua [16] and Venice (RIDEP network, 1988), as well as recent datasets from mountain localities in Veneto (CONECOFOR network and TESAF, Padua). For proposing that $\mathrm{pH}$ value, lower accuracy of dated analyses, sampling location, and the general reduction of emissions during the last decades have been taken into account.
} 
Table 1 Major-element chemical composition expressed as oxide weight percent of representative samples of Euganean trachyte from the Renaissance city walls of Padua determined by LA-ICPMS, on both surface (i.e., weathering crust or patina) and host rock (inner part)

\begin{tabular}{|c|c|c|c|c|c|c|c|c|c|c|c|}
\hline Sample & $\mathrm{SiO}_{2}$ & $\mathrm{TiO}_{2}$ & $\mathrm{Al}_{2} \mathrm{O}_{3}$ & $\mathrm{Fe}_{2} \mathrm{O}_{3}$ & $\mathrm{MnO}$ & $\mathrm{MgO}$ & $\mathrm{CaO}$ & $\mathrm{Na}_{2} \mathrm{O}$ & $\mathrm{K}_{2} \mathrm{O}$ & $\mathrm{P}_{2} \mathrm{O}_{5}$ & $\mathrm{SO}_{3}$ \\
\hline \multicolumn{12}{|l|}{ Calcite-rich alteration } \\
\hline \multicolumn{12}{|l|}{ SCR-01 } \\
\hline Surface & 8.57 & 0.02 & 1.14 & 0.58 & 0.04 & 1.49 & 85.85 & 0.17 & 0.12 & 0.69 & 0.38 \\
\hline Host rock & 63.69 & 0.12 & 18.09 & 0.76 & 0.01 & 0.14 & 4.40 & 6.18 & 4.56 & 0.04 & 0.45 \\
\hline \multicolumn{12}{|l|}{ GAR-03 } \\
\hline Surface & 52.04 & 0.17 & 13.40 & 3.98 & 0.31 & 1.21 & 16.29 & 3.28 & 0.83 & 3.21 & 1.18 \\
\hline Host rock & 67.17 & 0.09 & 18.08 & 0.91 & 0.00 & 0.20 & 1.51 & 5.75 & 5.70 & 0.12 & 0.10 \\
\hline \multicolumn{12}{|l|}{ CSN-03 } \\
\hline Surface & 55.10 & 0.40 & 11.59 & 3.51 & 0.09 & 1.51 & 15.60 & 3.00 & 0.97 & 1.42 & 2.93 \\
\hline Host rock & 65.78 & 0.11 & 18.31 & 2.04 & 0.01 & 0.35 & 1.03 & 5.82 & 5.63 & 0.04 & 0.06 \\
\hline \multicolumn{12}{|l|}{ SCR-05 } \\
\hline Surface & 58.50 & 0.19 & 13.81 & 3.31 & 0.05 & 0.72 & 10.42 & 2.77 & 0.55 & 1.22 & 0.44 \\
\hline Host rock & 67.89 & 0.30 & 15.96 & 1.97 & 0.02 & 0.59 & 1.69 & 5.26 & 5.21 & 0.17 & 0.12 \\
\hline \multicolumn{12}{|l|}{ Iron-rich alteration } \\
\hline \multicolumn{12}{|l|}{ SCR-07 } \\
\hline Surface & 40.97 & 0.39 & 14.27 & 21.19 & 0.15 & 1.22 & 5.22 & 1.96 & 0.57 & 7.47 & 0.82 \\
\hline Host rock & 68.09 & 0.15 & 17.23 & 1.34 & 0.02 & 0.40 & 1.21 & 5.32 & 5.64 & 0.10 & 0.08 \\
\hline \multicolumn{12}{|l|}{ Weak alteration } \\
\hline \multicolumn{12}{|l|}{ FST-07 } \\
\hline Surface & 66.20 & 0.13 & 17.71 & 2.99 & 0.12 & 0.33 & 3.73 & 5.07 & 0.91 & 0.72 & 0.65 \\
\hline Host rock & 69.08 & 0.06 & 16.46 & 0.84 & 0.01 & 0.12 & 2.01 & 5.20 & 4.33 & 0.07 & 0.11 \\
\hline \multicolumn{12}{|l|}{ Gypsum-rich alteration } \\
\hline \multicolumn{12}{|l|}{ FST-05 } \\
\hline Surface & 5.44 & 0.01 & 0.41 & 0.11 & 0.00 & 0.17 & 66.07 & 1.34 & 0.12 & 0.58 & 24.87 \\
\hline Host rock & 70.62 & 0.23 & 14.93 & 1.29 & 0.01 & 0.32 & 1.05 & 4.01 & 6.32 & 0.03 & 0.19 \\
\hline Average composition of Euganean trachyte ${ }^{a}$ & 66.02 & 0.66 & 16.77 & 3.26 & 0.06 & 0.66 & 1.42 & 5.04 & 5.35 & 0.21 & 0.01 \\
\hline
\end{tabular}

The samples are divided by different types of alteration and sampling location as in Fig. 2 (SCR, Bastione Santa Croce; GAR, Torrione dell'Arena; CSN, Bastione Castelnuovo; FST, Torrione Venier)

a Bulk-rock chemical composition determined by X-ray fluorescence and averaged among 86 fresh trachyte samples collected on the Euganean Hills in 40 different quarries and outcrops [32]

the influence of the industrial area of Venice-Porto Marghera, one of the largest coastal industrial zones in Europe, located $30 \mathrm{~km}$ far from Padua, cannot be ruled out. In its area of over $20 \mathrm{~km}^{2}$, chemical, petrochemical and petroleum industries, refineries, thermal power stations, metallurgical industries, air separation and naturalgas processing plants, incinerators, etc. are operational. The emissions comprise mainly $\mathrm{SO}_{2}, \mathrm{NO}_{x}, \mathrm{CO}, \mathrm{PM}$, and VOC [37-39], which are easily transported to Padua by winds having usually a NE direction.

\section{Exogenous processes}

The mineralogical and chemical identity of the alterations of Euganean trachyte can be related to air pollution, so that composition of the weathering crusts and patinas turns out to be a marker for the relevant environmental conditions and their evolution.

The enrichment in $\mathrm{C}$ and heavy metals can be traced back to the particulate deriving mostly from road traffic, emitted by diesel and gasoline-powered vehicles, and domestic combustion of woody biomass. These are the main sources of total suspended particulate (TSP) in Padua, according to the emission projections by ARPAV agency $[40]^{2}$ summarized in Fig. 9. A further major

\footnotetext{
${ }^{2}$ INEMAR projections by ARPAV agency contain space- and time-based estimations of the yearly emissions in the atmosphere generated by several anthropic and natural activities that, given the complexity and amount of the possible sources, could not be all exactly calculated. The estimations are based on both real measured data and theoretical indicators, the latter inferred from statistical data and exploratory surveys concerning population, territory, economy, development, etc. [40].
} 


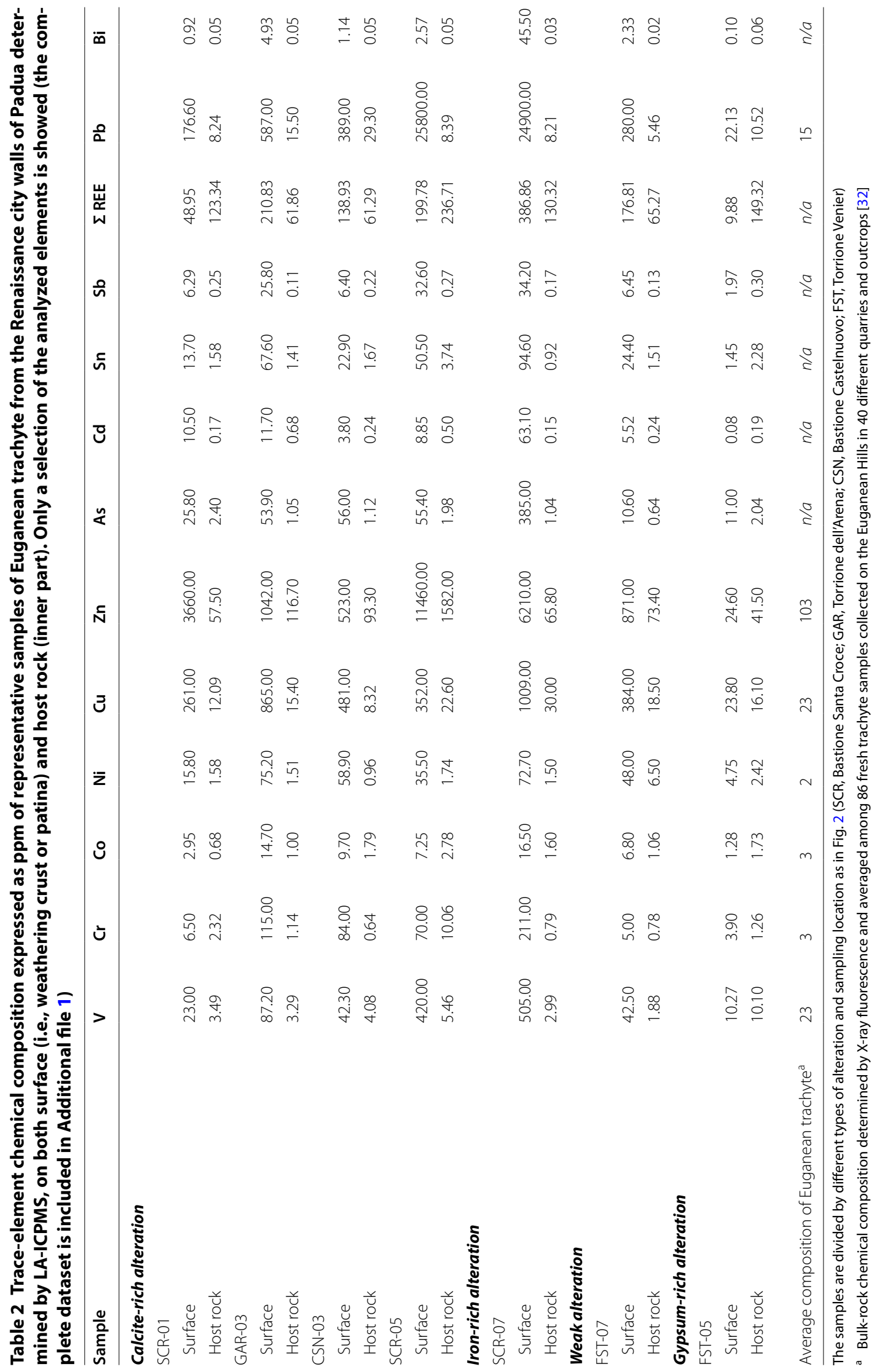




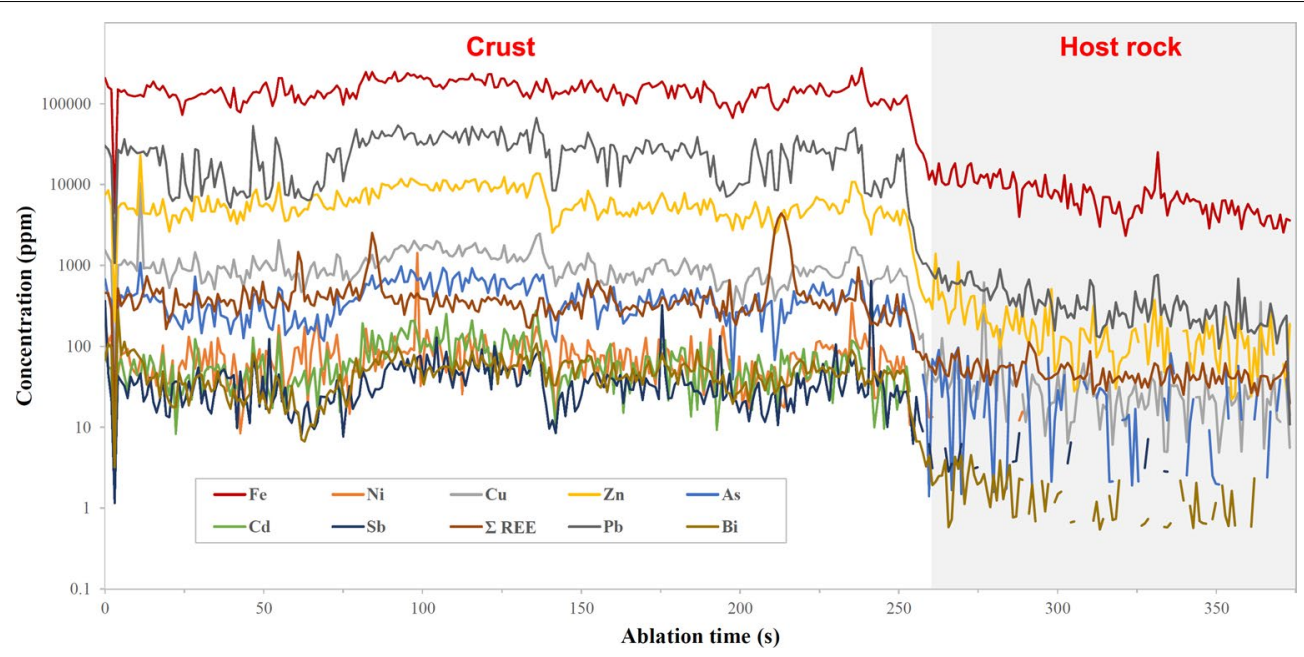

Fig. 7 Time-resolved LA-ICPMS spectrum obtained from a Fe-rich crust of Euganean trachyte, by a combined profile and spot analysis: crust surface was first ablated along a line and eventually drilled through, until reaching the host rock
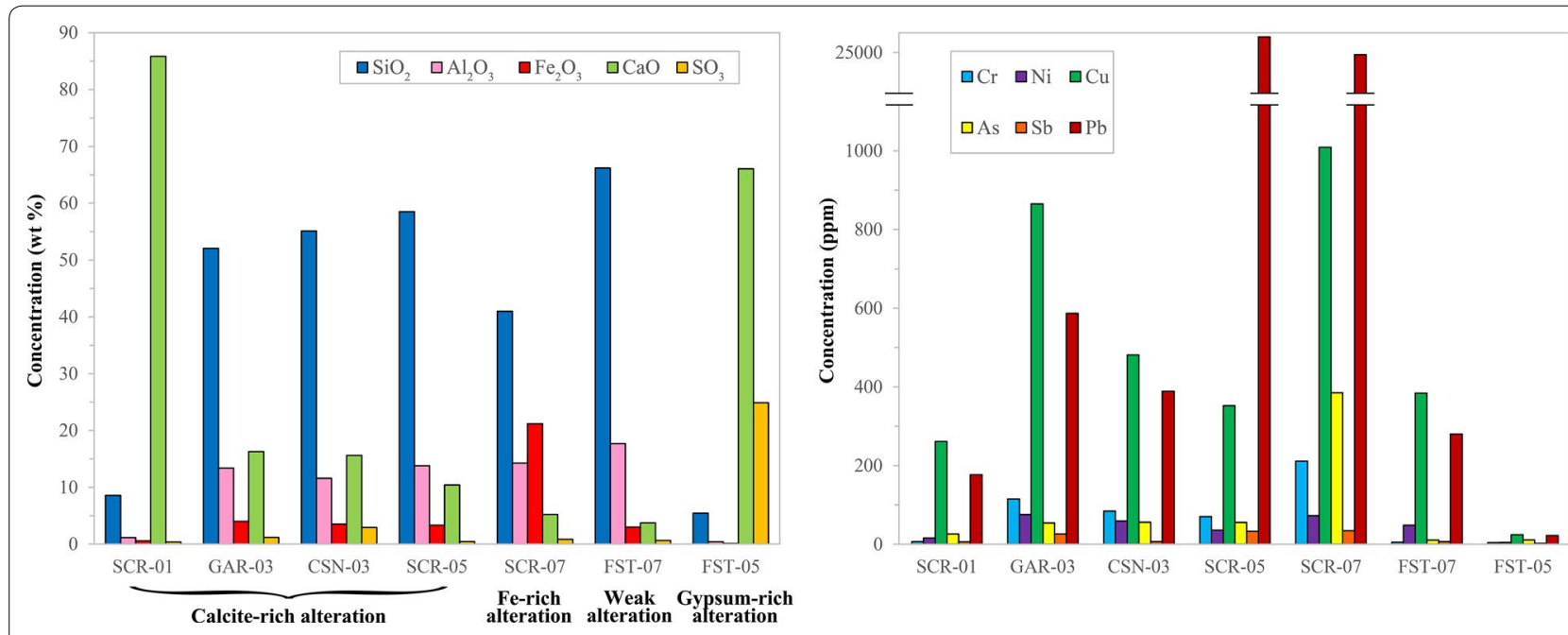

Fig. 8 Comparison of the major- and trace-element composition measured by LA-ICPMS on the weathering crusts and patinas of representative samples of Euganean trachyte. Sample names and compositions refer to Tables 1 and 2

source of particulate is fuel-free industrial processes in the steel mill ("productive processes"); as indicated in Table 4, its emissions have a relatively high content of $\mathrm{Pb}$, $\mathrm{Ni}$, and As, so this can be directly related to the enrichment in heavy metals detected on the weathering crusts. By comparison, TSP produced by the local incinerator ("waste treatment and disposal") is almost negligible. If the contribution from the industrial area of Venice-Porto Marghera is also considered, a further supply of carbonaceous pollutants and heavy metals can be identified mainly from the power stations, refinery, petroleum industries, and the related employment of fuels and machines. Conditions of high air humidity and precipitation and strong wind are the most favorable for pollutant dispersion, so that summer can be considered the least dangerous season. Carbonaceous and metallic particles act as catalysts, so their accumulation enhance further stone alteration and crust growth [41].

Among other exogenous processes contributing to the weathering of Euganean trachyte, it is worth mentioning the possible reactions leading to the formation of the carbonate crusts. Considering the originally low concentration of calcite and dolomite in the host rock, the only plausible and consistent source for these phases is identified in lime and $\mathrm{Mg}$-lime mortars used in the walls of Padua for joining trachyte blocks. Indeed, Ca carbonate 
Table 3 Climatic parameters measured in Padua averaged from 2000 to 2015. Source: ARPAV

\begin{tabular}{|c|c|c|c|}
\hline Climatic parameter & Value & Climatic parameter & Value \\
\hline Temperature $\left({ }^{\circ} \mathrm{C}\right)$ & & Precipitation (mm) & \\
\hline Annual mean & 14.5 & Annual total & 959 \\
\hline Annual mean min & 10.7 & Lowest annual total & 561 \\
\hline Annual mean max & 19.1 & Highest annual total & 1395 \\
\hline Lowest monthly mean and monthly mean min (month) & 3.9/1.5 (January) & Lowest monthly total (month) & 58 (January) \\
\hline Highest monthly mean and monthly mean max (month) & 24.7/30.2 (July) & Highest monthly total (month) & 107 (November) \\
\hline Relative humidity (\%) & & Precipitation days & \\
\hline Annual mean & 74 & Annual total ( $\geq 1 \mathrm{~mm})$ & 84 \\
\hline Annual mean min & 53 & & \\
\hline Annual mean max & 91 & Solar irradiance $\left(\mathrm{MJ} / \mathrm{m}^{2}\right)$ & \\
\hline Lowest monthly mean and monthly mean min (month) & 65/43 (July) & Annual total (Legnaro, 1994-2015) & 5005 \\
\hline \multirow[t]{2}{*}{ Highest monthly mean and monthly mean max (month) } & 84/94 (November) & Wind direction & \\
\hline & & Annual mean & $\mathrm{NE}$ \\
\hline
\end{tabular}

may be dissolved from mortars by acid solutions and reprecipitate in basic ones; calcite is less stable, i.e., its dissolution is faster, when $\mathrm{pH}$ is lower than about 5-6: dissolution rate increases with increasing $\mathrm{H}^{+}$activity, in high-acidity regime, or $\mathrm{CO}_{2}$ partial pressure, in low-acidity regime [42-44]. As reported above, average $\mathrm{pH}$ of rainfall in Padua is around 5.5-6, just around the limit of calcite stability. This means that $\mathrm{pH}$ fluctuations ${ }^{3}$ to higher acidity may increase leachability of $\mathrm{Ca}$ carbonate from mortars; the resulting solution containing leached $\mathrm{Ca}(\mathrm{OH})_{2}$, thus an alkaline medium [36], continues its short-range path, and may easily reach trachyte elements (especially subvertical substrates), wetting their surface and penetrating into pores; finally, calcite reprecipitates, taking advantage of the alkaline $\mathrm{pH}$. Carbonate recrystallization episodes might be more common in summertime, whereas dissolution process possibly takes place more frequently during late fall and winter: in the cold season, atmosphere acidity is generally higher due to domestic heating and related emissions, and low temperatures increase calcite solubility [45]; higher humidity and precipitation represent other favorable factors, as well as the recurrence of misty days, with fog being more acid than rainfall, with $\mathrm{pH}$ even below $4[13,36]$.

The role of neighboring mortars acting as Ca source for trachyte weathering has been outlined by previous studies too [21, 22, 27]. It seems to be confirmed also

\footnotetext{
${ }^{3} \mathrm{pH}$ fluctuations of an aqueous solution can occur due to leaching of stones/mortars or solubilization of acid particles previously dry-deposited on their surface. Fluctuations also depend on the current general air quality and other large-scale factors: for example, a short drizzle or the initial stage of a rainfall are more acid, since the highly-soluble anthropogenic pollutants are first gathered; in a later stage, airborne alkaline agents reacting with slower kinetics and solubility-e.g., $\mathrm{NH}_{3}$ from agricultural fertilizers, soil particles, wind-transported Saharan dust, etc.-make water $\mathrm{pH}$ increase $[15,16]$.
}

by the formation of the gypsum crusts very close to a mortar joint, and the possible supply of quartz, sulfates, chlorides, etc. from the mortar aggregate. The layers of amorphous silica might develop from the dissolution of either the mortar or the rock-forming silicate minerals or glass-bearing domains in trachyte [46]. Quartz might be also derived by Saharan dust, long-range transported from Africa by Sirocco: when this wind rises to pass over the Alps further north than Padua, the desert particles, composed of silicates and carbonates, are scavenged by rainfall and may precipitate in the Po Plain $[15,16]$.

On the other hand, the gypsum crusts might be also connected to anthropogenic air pollutants, i.e., to $\mathrm{SO}_{2}$ oxidation and hydration and the well-known subsequent reaction of $\mathrm{H}_{2} \mathrm{SO}_{4}$ with a Ca carbonate substrate, in this case formed on trachyte after mortar leaching. The high degree of fracturing of the underlying host rock suggests an initial penetration of Ca-rich solutions in the outer pores, then producing crystallization pressures during water evaporation up to rock failure. Gypsum possibly formed after subsequent $\mathrm{Ca}$ loading and growing outwards of the carbonate crystallization layer, on surfaces sheltered from direct rainfall and washing out. Concerning $\mathrm{SO}_{2}$ supply, the most important contribution is given by the emissions of the steel mill. Anyway, the overall concentration of $\mathrm{SO}_{2}$ is rather low in Padua and not comparable to that typical of big urban and industrial centers [13], and presumably it was so even in the past. Thisother than the carbonate-poor composition of trachytejustifies the very limited extension of the gypsum crusts and their rare occurrence [47]. A hypothesis that can be completely discarded is the nucleation of gypsum directly from soot absorbing pollutants [48], given its low concentration and, on the other hand, the large extension of the gypsum crusts. 


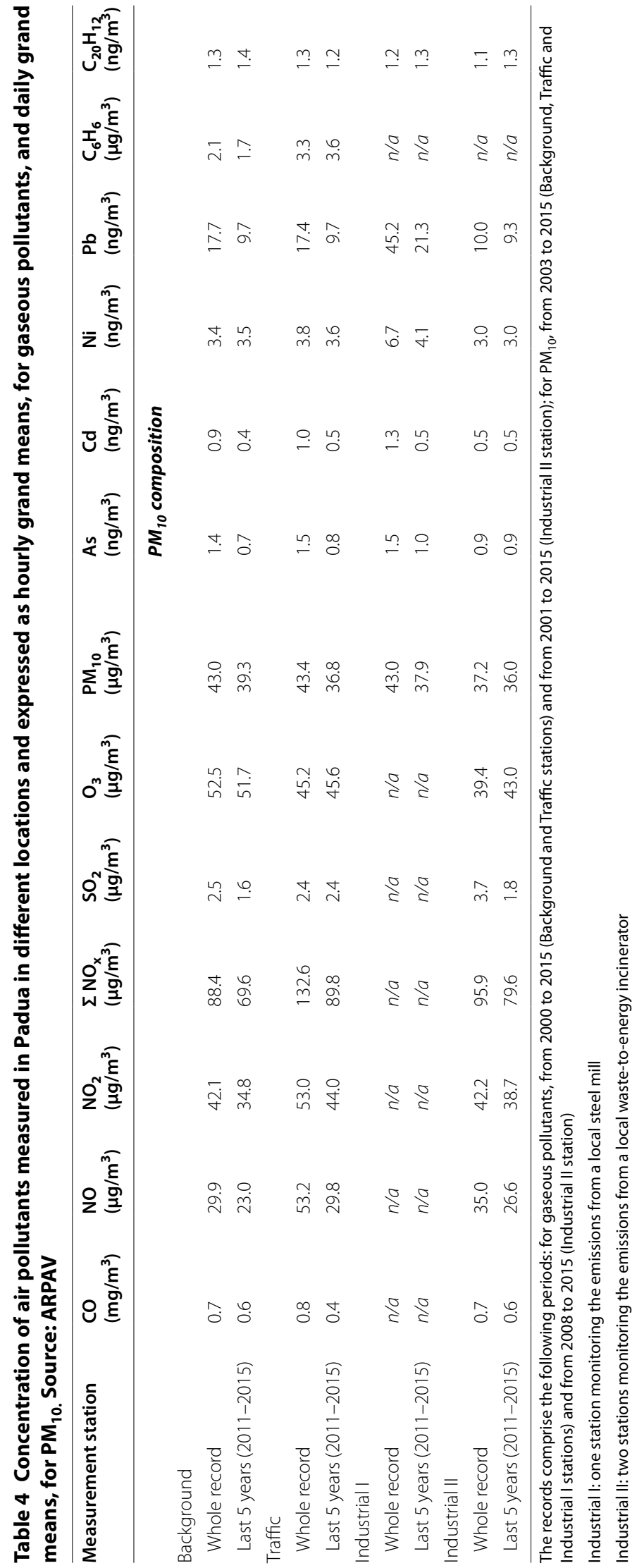




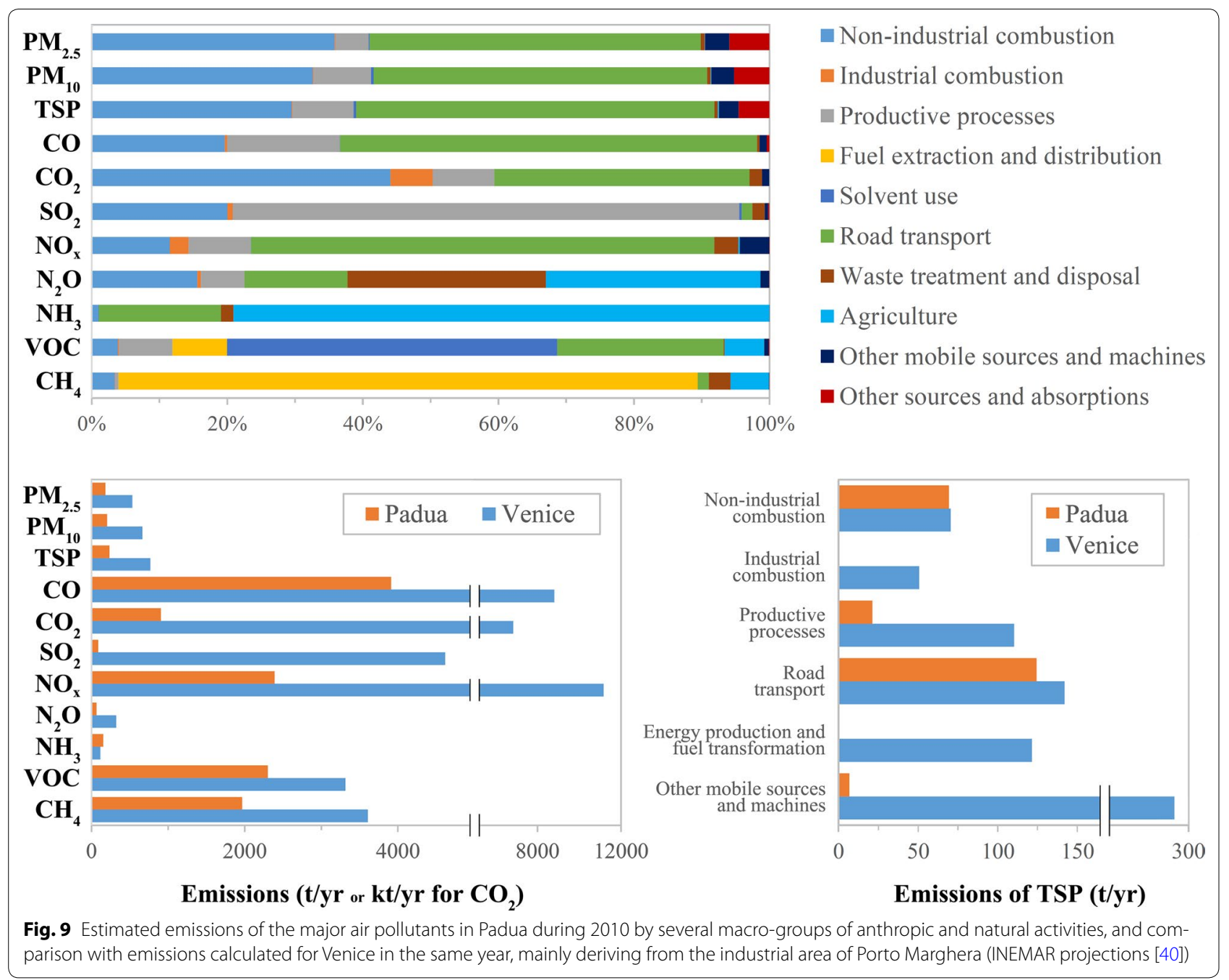

Finally, it is worth reminding that no evident effect of interaction between trachyte and sea salts carried by wind or rainwater was noticed. Indeed, the typical weathering products connected to coastal environment identified in previous studies [22, 23], in particular high concentrations of halite, were not found here. The scant chlorides detected have to be traced back to mortar composition instead, as stated above.

On the other hand, composition of the weathering products of Euganean trachyte can be compared to that detected in inland environment on Drachenfels trachyte studied by Graue et al. [27]. The main difference lies in a greater incidence of $\mathrm{CaO}$ enrichment and calcite recrystallization on surface alteration of Euganean trachyte, whereas the framboidal crusts analyzed on Drachenfels trachyte in an urban and industrial setting generally are thicker (centimetric size), richer in well-developed gypsum crystals, and may show stronger sulfation and higher concentration of heavy metals. Nevertheless, if $\mathrm{Pb}$ concentration is the term for comparison, that analyzed in the crusts and patinas of Euganean trachyte is often close to the typical values measured in European cities, i.e., from few hundreds ppm up to 2000 ppm [27].

\section{Stone leaching}

Some features of the weathering crusts and patinas of Euganean trachyte can be explained by intrinsic factors, in particular the Fe-rich alterations. Microscopic examinations disclosed an enrichment in fine-grained $\mathrm{Fe}$ oxides and hydroxides and amorphous Fe in the proximity of biotite phenocrysts and, secondarily, magnetite and ilmenite crystals (Fig. 10). This suggests Fe mobilization from the minerals by leaching and migration to surface, forming brown-reddish alteration layers. Leaching might have also occurred at the expense of mafic xenoliths [23] or pervasive migration fronts of Fe oxides/hydroxides, genetically linked to post-magmatic processes [32]. Leaching of biotite seems more likely, since solubility of 

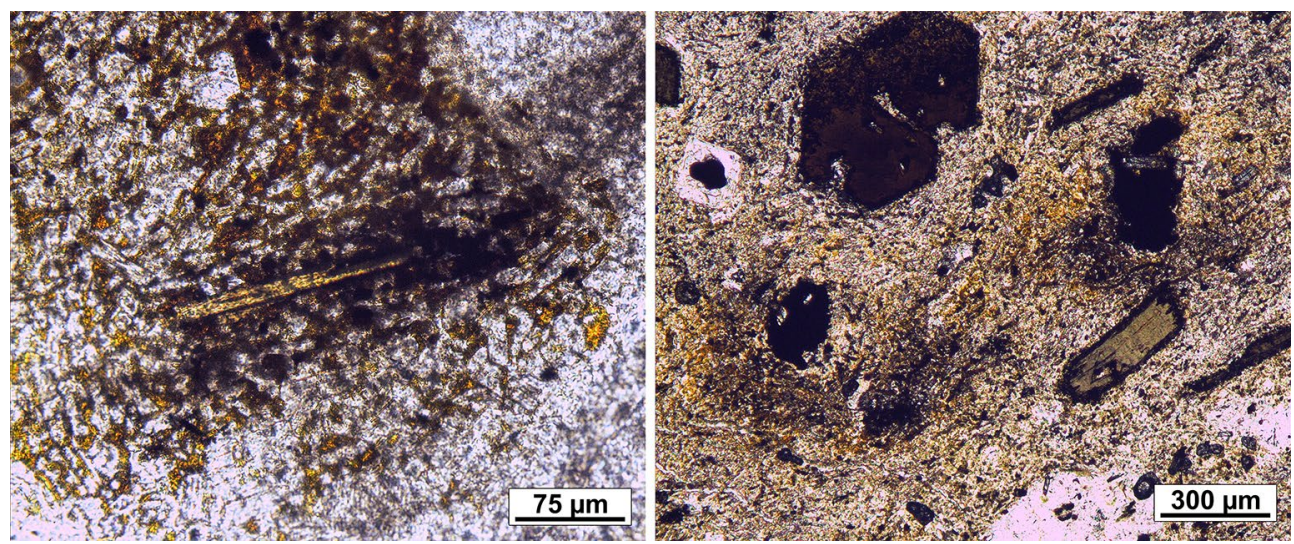

Fig. 10 Thin-section photomicrographs of samples of Euganean trachyte with Fe-rich crusts, showing dispersion of fine-grained Fe oxides/hydroxides or Fe in amorphous state around a biotite crystal (left) and two opaque minerals (i.e., magnetite or ilmenite) (right), apparently indicating near-surface mineral leaching

magnetite and ilmenite is lower. $\mathrm{Fe}^{2+}$ release from the octahedral layers of biotite is strongly $\mathrm{pH}$ dependent: rate of dissolution linearly increases with decreasing $\mathrm{pH}$, but the reaction is significant only for values lower than $4-5$ [49-51]. The environmental conditions leading to the formation of the Fe-rich crusts and patinas would be similar to those described for the calcite crusts, involving $\mathrm{pH}$ fluctuations around the limit of the stability field even of biotite; in this case, however, its lower leachability if compared to that of calcite requires a more acid environment for dissolution to get started. Finally, a minor contribution of PM to Fe enrichment of trachyte surfaces must be taken into account, however that is not the main source, as also confirmed by the absence of Fe compounds in the incoherent and powdery surface deposits of exogenous origin.

A leaching process of the host-rock has been supposed also with regard to dissolution of plagioclase and release of $\mathrm{Ca}^{2+}$ cations, as an alternative or concurrent mechanism of formation of the calcite crusts. In Euganean trachyte, plagioclase represents one of the main mineral phases, it has a prevalent oligoclase-andesine composition with an average $\mathrm{CaO}$ content of $6 \%$ [32], so theoretically it is a possible source of $\mathrm{Ca}[52,53]$. However, the overall $\mathrm{CaO}$ content of the bulk rock is rather low on average (1.4\%, see Table 1). Additionally, in acid solutions, Ca leachability from plagioclase is rather low, especially taking calcite as a term of comparison or even $\mathrm{Fe}$ release from biotite [46, 54]. Leaching is also facilitated in fine-grained crystals, whereas plagioclases are among the coarsest phenocrysts in Euganean trachyte, even reaching a centimetric size. Moreover, clay minerals, typically resulting from feldspar alteration, were detected only in minor amounts (their concentration in the host rock is also rather low or negligible). For all these reasons, plagioclase cannot be considered the primary source of such a high concentration of carbonates in the crusts, although its contribution cannot be totally excluded.

\section{Conclusions}

The crusts and patinas of Euganean trachyte related to urban weathering have mostly limited thickness and extension. They are rich in heavy metals and carbonaceous matter, which promote further accumulation of pollutants, mainly derived from fuel use in road transport and domestic combustion, and, secondarily, shortand medium-range industrial emissions. These products are typically embedded in matrixes rich in calcite or Fe (either as oxides/hydroxides or amorphous components). The crusts and patinas also include grains of quartz, dolomite, and other minor components, such as metallic and aluminum-silicon particles, chlorides, etc. The high concentration of carbonates cannot derive from host rock components; $\mathrm{pH}$-controlled dissolution, mobilization, and recrystallization of carbonates from nearby lime mortars used in joints seems the most plausible source of $\mathrm{Ca}$. This process may also occur on seasonal basis, depending on $\mathrm{pH}$ fluctuations. A secondary and very limited source of $\mathrm{Ca}$ can be represented by dissolution of plagioclases. A more likely intrinsic process of alteration affects biotite and other Fe-bearing minerals, through $\mathrm{pH}$-dependent leaching of $\mathrm{Fe}$ and its migration to surface. Other alteration forms recognized comprise powdery deposits and gypsum crusts, but they do not occur commonly. The latter possibly derive from the contribution of $\mathrm{SO}_{2}$ pollutant, having a rather low concentration in the air though; the presence of sulfate impurities in mortar aggregate and their leaching can be alternatively invoked. 
When present, thick, homogeneous and well-developed crusts, rich in either calcite or gypsum, partially shield the host rock from further pollutant absorption.

From this study, it arises that most of the alteration products of Euganean trachyte are due to exogenous processes, whereas the stone itself does not have particular compositional features prone to trigger major dangerous mechanisms of decay. Generally, composition of the weathering crusts and patinas of Euganean trachyte proves to be an informative marker for the relevant environmental conditions and their evolution, with a strict link with air pollution determined by different anthropic pollution sources.

Further studies are needed concerning trachyte-mortar interaction, in order to explore to what extent mortar affects stone surface alteration and in which microclimatic conditions, what is the mobilization potential of the leached components, and the influence of different mortar recipes.

\section{Additional file}

Additional file 1. Trace-element chemical composition expressed as ppm of representative samples of Euganean trachyte from the Renaissance city walls of Padua determined by LA-ICPMS, on both surface (i.e., weathering crust or patina) and host rock (inner part). The samples are divided by different types of alteration and sampling location as in Fig. 2 (SCR, Bastione Santa Croce; GAR, Torrione dell'Arena; CSN, Bastione Castelnuovo; FST, Torrione Venier).

\section{Abbreviations}

EDS: energy-dispersive X-ray spectroscopy; FE-SEM: field-emission scanning electron microscope; LA-ICPMS: laser ablation inductively coupled plasma mass spectrometry; PM: particulate matter; SEM: scanning electron microscope; TSP: total suspended particulate; VOC: volatile organic compounds; XRPD: X-ray powder diffraction.

\section{Authors' contributions}

This paper has been extracted from the Ph.D. thesis written by $L G$, after a research work supervised by CM and co-supervised by LM at the University of Padova. SS supervised the research activities carried out at the University of Göttingen. Finally, KS provided support for the LA-ICPMS analyses. All authors read and approved the final manuscript.

\section{Author details}

1 Department of Geosciences, University of Padova, Via Gradenigo 6, 35131 Padua, Italy. ${ }^{2}$ Geoscience Center, Georg-August-Universität Göttingen Goldschmidtstrasse 3, 37077 Göttingen, Germany.

\section{Acknowledgements}

The authors thank Kirsten Techmer and Klaus Wemmer (Uni. Göttingen) for their support during the SEM and XRPD analyses, respectively. The authors are very grateful to Hans Ruppert (Uni. Göttingen) for the helpful discussions on the results. The review and comments on an early draft of the manuscript by Giuseppe Cultrone (Uni. Granada) are also much appreciated. Thanks are due to Comune di Padova for kindly authorizing sampling on the city walls and to Comitato Mura di Padova, in particular Fabio Bordignon, for providing information on the building phases and past conservation interventions. Finally, ARPAV agency is acknowledged for providing the climatic and air quality data, and Dario Camuffo (CNR-ISAC, Padova) and Michela Rogora (CNR-ISE, Verbania) for further information on local environmental parameters.
Competing interests

The authors declare that they have no competing interests.

Availability of data and materials

An extra database of chemical data is provided as supplementary on-line material ("Additional file 1").

\section{Consent for publication}

Not applicable.

\section{Ethics approval and consent to participate}

Not applicable.

\section{Funding}

University of Padova (Research Project No. CPDA151883/15 of CM), DAAD (German Academic Exchange Service, Short-Term Research Grants 201657214227 to LG), European Union (Erasmus + grant to LG).

\section{Publisher's Note}

Springer Nature remains neutral with regard to jurisdictional claims in published maps and institutional affiliations.

Received: 30 June 2017 Accepted: 13 September 2017

Published online: 25 October 2017

\section{References}

1. Brimblecombe P, Camuffo D. Long term damage to the built environment. In: Brimblecombe P, editor. The effects of air pollution on the built environment, vol. 2. London: Imperial College Press; 2003. p. 1-30 (Air Pollution Reviews)

2. Brimblecombe P. Environment and architectural stone. In: Siegesmund S, Snethlage R, editors. Stone in architecture. Properties, durability. 5th ed. Berlin: Springer; 2014. p. 317-47.

3. Sohn I. Long-term energy projections: what lessons have we learned? Energy Policy. 2007;35:4574-84.

4. Wolde-Rufael Y. Coal consumption and economic growth revisited. Appl Energy. 2010;87:160-7.

5. Thomas LP. Coal resources and reserves. In: Osborne D, editor. The coal handbook: towards cleaner production, vol. 1. Amsterdam: Elsevier, Woodhead Publishing Series in Energy; 2013. p. 80-106.

6. Tollefson J. How Trump plans to wipe out Obama-era climate rules. Nature. 2017. doi:10.1038/nature.2017.21726.

7. Guerreiro CBB, Foltescu V, de Leeuw F. Air quality status and trends in Europe. Atmos Environ. 2014;98:376-84.

8. Grossi CM, Brimblecombe P. Effect of long-term changes in air pollution and climate on the decay and blackening of European stone buildings. In: Prrikryl R, Smith BJ, editors. Building stone decay: from diagnosis to conservation, vol. 271. London: Geological Society, Special Publications; 2007. p. 117-30.

9. Auras M, Beer S, Bundschuh P, Eichhorn J, Mach M, Scheuvens D, Schorling M, von Schumann J, Snethlage R, Weinbruch S. Traffic-related immissions and their impact on historic buildings: implications from a pilot study at two German cities. Environ Earth Sci. 2013;69:1135-47.

10. Saiz-Jimenez C. Organic pollutants in the built environment and their effect on the microorganisms. In: Brimblecombe P, editor. The effects of air pollution on the built environment, vol. 2. London: Imperial College Press; 2003. p. 183-226 (Air Pollution Reviews)

11. Saiz-Jimenez C. Deposition of airborne organic pollutants on historic buildings. Atmos Environ. 1993;27B(1):77-85.

12. Sabbioni $C$. Contribution of atmospheric deposition to the formation of damage layers. Sci Total Environ. 1995;167:49-55.

13. Charola AE, Ware R. Acid deposition and the deterioration of stone: a brief review of a broad topic. In: Siegesmund S, Weiss T, Vollbrecht A, editors. Natural stone, weathering phenomena, conservation strategies and case studies, vol. 205. London: Geological Society, Special Publications; 2002. p. 393-406. 
14. Watt J, Hamilton R. The soiling of buildings by air pollution. In: Brimblecombe P, editor. The effects of air pollution on the built environment, vol. 2. London: Imperial College Press; 2003. p. 289-334 (Air Pollution Reviews).

15. Camuffo D, Del Monte M, Ongaro A. The pH of the atmospheric precipitation in Venice, related to both the dynamics of precipitation events and the weathering of monuments. Sci Total Environ. 1984;40:125-39.

16. Camuffo D, Bernardi A, Zanetti M. Analysis of the real-time measurement of the $\mathrm{pH}$ of rainfall at Padova, Italy: seasonal variation and meteorological aspects. Sci Total Environ. 1988;71:187-200.

17. Camuffo D. Physical weathering of stones. Sci Total Environ. 1995;167:1-14.

18. Sabbioni C. Mechanisms of air pollution damage to stone. In: Brimblecombe P, editor. The effects of air pollution on the built environment, vol. 2. London: Imperial College Press; 2003. p. 63-106 (Air Pollution

\section{Reviews).}

19. Grissom CA. The deterioration and treatment of volcanic stone: a review of the literature. In: Charola AE, Koestler RJ, Lombardi G, editors. Proceedings of the international meeting "Lavas and Volcanic Tuffs", Easter Island, Chile, 25-31 October 1990. p. 3-29.

20. St Seymour K, Sahin Guchan N, Lamera S, Hatziapostolou A, Kouli M, Vamvoukakis C. Romancing the stone: construction of monuments \& works of art from volcanic rock. In: Proceedings of the 7th pan-hellenic geographical conference of the Hellenic Geographical Association, Mytilene, Lesvos, Greece, 14-17 October 2004. E1K164.

21. Prudêncio MI, Waerenborgh JC, Gouveia MA, Trindade MJ, Alves E, Sequeira Braga MA, Alves CA, Figueiredo MO, Silva T. Degradation processes of trachytes in monument façades, Azores, Portugal. In: Arehart GB, Hulston JR, editors. Water-rock interaction. Rotterdam: Balkema; 1998. p. 391-4.

22. Alves CAS, Sequeira Braga MA, Trancoso A. Saline pollution in trachyte monuments of the Azores Islands (Portugal). In: Fassina V, editor. Proceedings of the 9th international congress on deterioration and conservation of stone, Venezia, Italy, 19-24 June 2000. p. 225-33.

23. Lazzarini L, Antonelli F, Cancelliere S, Conventi A. The deterioration of Euganean trachyte in Venice. In: Lukaszewicz JW, Niemcewicz P, editors. Proceedings of the 11 th international congress on deterioration and conservation of Stone, Torun, Poland, 15-20 September 2008. p. 153-63.

24. Langella A, Calcaterra D, Cappelletti P, Colella A, D'Albora MP, Morra V, De Gennaro M. Lava stones from Neapolitan volcanic districts in the architecture of Campania region, Italy. Environ Earth Sci. 2009;59:145-60.

25. Germinario L, Siegesmund S, Maritan L, Mazzoli C. Petrophysical and mechanical properties of Euganean trachyte and implications for dimension stone decay and durability performance. Environ Earth Sci. 2017. doi:10.1007/s12665-017-7034-6.

26. Gillhuber S, Lehrberger G, Thuro K. Teplá trachyte weathering phenomena and physical properties of a rare volcanogenic building stone. In: Proceedings of IAEG 2006-engineering geology for tomorrow's cities, Nottingham, UK, 6-10 September 2006. 469, p. 1-11.

27. Graue B, Siegesmund S, Oyhantcabal P, Naumann R, Licha T, Simon K. The effect of air pollution on stone decay: the decay of the Drachenfels trachyte in industrial, urban, and rural environments-a case study of the Cologne, Altenberg and Xanten cathedrals. Environ Earth Sci. 2013;69:1095-124.

28. Mazzi G, Verdi A, Dal Piaz V. Le mura di Padova. Percorso storico-architettonico. Padova: II Poligrafo; 2002.

29. Fadini U, editor. Mura di Padova. Guida al sistema bastionato rinascimentale. Vicenza: In Edibus; 2013.

30. Milani L, Beccaluva L, Coltorti M. Petrogenesis and evolution of the Euganean Magmatic Complex, Veneto region, north-east Italy. Eur J Miner. 1999;11:379-99.

31. Bartoli O, Meli S, Bergomi MA, Sassi R, Magaraci D, Liu DY. Geochemistry and zircon $\mathrm{U}-\mathrm{Pb}$ geochronology of magmatic enclaves in trachytes from the Euganean Hills (NE Italy): further constraints on Oligocene magmatism in the eastern southern Alps. Eur J Miner. 2015;27:161-74.

32. Germinario L, Hanchar JM, Sassi R, Maritan L, Cossio R, Borghi A, Mazzoli C. New petrographic and geochemical tracers for recognizing the provenance quarry of trachyte of the Euganean Hills, northeastern Italy. Geoarchaeology 2017; (in press).

33. Germinario L, Zara A, Maritan L, Bonetto J, Hanchar JM, Sassi R, Siegesmund S, Mazzoli $C$. Tracking trachyte on the Roman routes: provenance study of Roman infrastructure and insights into ancient trades in northern Italy. Geoarchaeology 2017; (in press)

34. Simon K. LA-ICP-MS transient signal quantification of NIST, USGS and MPI-DING glasses by ratioing, standardization, normalization and correction (RSNC). Germany: Geowissenschaftliches Zentrum, Georg-AugustUniversität Göttingen; 2015 (Unpublished)

35. Török Á, Licha T, Simon K, Siegesmund S. Urban and rural limestone weathering; the contribution of dust to black crust formation. Environ Earth Sci. 2011;63:675-93.

36. Steiger M, Charola AE, Sterflinger K. Weathering and deterioration. In: Siegesmund S, Snethlage R, editors. Stone in architecture. Properties, durability. 5th ed. Berlin: Springer; 2014. p. 225-316.

37. ARPAV. Rapporto ambientale d'area di Porto Marghera-bilancio ambientale 1998-2007. Venezia: ARPAV; 2007.

38. ARPAV. Tavolo tecnico cementifici- $1^{\circ}$ rapporto tecnico. Padova: ARPAV; 2009.

39. ARPAV. Monitoraggio della qualità dell'aria presso il termovalorizzatore di San Lazzaro-relazione tecnica. Padova: ARPAV; 2015.

40. ARPAV. Inventario regionale delle emissioni in atmosfera INEMAR Veneto 2010—relazione generale. Venezia: ARPAV; 2015.

41. Simão J, Ruiz-Agudo E, Rodriguez-Navarro C. Effects of particulate matter from gasoline and diesel vehicle exhaust emissions on silicate stones sulfation. Atmos Environ. 2006;40:6905-17.

42. Fredd CN, Fogler HS. The kinetics of calcite dissolution in acetic acid solutions. Chem Eng Sci. 1998:53(22):3863-74.

43. Arvidson RS, Evren Ertan I, Amonette JE, Luttge A. Variation in calcite dissolution rates: a fundamental problem? Geochim Cosmochim Acta. 2003;67(9):1623-34.

44. Dolgaleva IV, Gorichev IG, Izotov AD, Stepanov VM. Modeling of the effect of $\mathrm{pH}$ on the calcite dissolution kinetics. Theor Found Chem Eng. 2005;39(6):614-21.

45. Deer WA, Howie RA, Zussman J. An introduction to the rock-forming minerals. 3rd ed. London: The Mineralogical Society; 2013.

46. Brantley SL, Olsen AA. Reaction kinetics of primary rock-forming minerals under ambient conditions. In: Holland HD, Turekian KK, editors. Treatise on geochemistry, vol. 7. 2nd ed. Amsterdam: Elsevier; 2014. p. 69-113.

47. Germinario L, Andriani GF, Laviano R. Petrography, mineralogy, chemical and technical properties of the building stone of Ostuni Cathedral (Italy): inferences on diagnostics and conservation. Period Miner. 2014:83(3):379-400. doi:10.2451/2014PM0021.

48. Camuffo D. Deterioration processes of historical monuments. In: Schneider T, editor. Acidification and its policy implications. Amsterdam: Elsevier; 1986. p. 189-221.

49. Acker JG, Bricker OP. The influence of $\mathrm{pH}$ on biotite dissolution and alteration kinetics at low temperature. Geochim Cosmochim Acta. 1992;56:3073-92.

50. Bray AW, Benning LG, Bonneville S, Oelkers EH. Biotite surface chemistry as a function of aqueous fluid composition. Geochim Cosmochim Acta. 2014;128:58-70.

51. Bray AW, Oelkers EH, Bonneville S, Wolff-Boenisch D, Potts NJ, Fones G, Benning LG. The effect of $\mathrm{pH}$, grain size, and organic ligands on biotite weathering rates. Geochim Cosmochim Acta. 2015;164:127-45.

52. Blum AE, Stillings LL. Feldspar dissolution kinetics. In: White AF, Brantley SL, editors. Chemical weathering rates of silicate minerals, vol. 31. Washington, DC: Mineralogical Society of America; 1995. p. 291-351 (Reviews in mineralogy).

53. White AF, Buss HL. Natural weathering rates of silicate minerals. In: Holland HD, Turekian KK, editors. Treatise on geochemistry, vol. 7. 2nd ed. Amsterdam: Elsevier; 2014. p. 115-55.

54. Snäll S, Liljefors T. Leachability of major elements from minerals in strong acids. J Geochem Explor. 2000;71:1-12. 